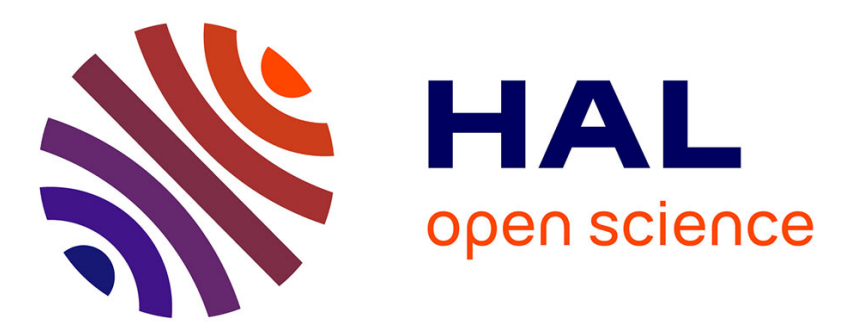

\title{
Flavonol glycosides and lignans from the leaves of Opilia amentacea
}

\author{
Abdulmagid Alabdul Magid, Anaëlle Abdellah, Virginie Pecher, Laure \\ Pasquier, Dominique Harakat, Laurence Voutquenne-Nazabadioko
}

\section{- To cite this version:}

Abdulmagid Alabdul Magid, Anaëlle Abdellah, Virginie Pecher, Laure Pasquier, Dominique Harakat, et al.. Flavonol glycosides and lignans from the leaves of Opilia amentacea. Phytochemistry Letters, 2017, 21, pp.84 - 89. 10.1016/j.phytol.2017.05.023 . hal-01834114

\section{HAL Id: hal-01834114 \\ https://hal.univ-reims.fr/hal-01834114}

Submitted on 25 Nov 2021

HAL is a multi-disciplinary open access archive for the deposit and dissemination of scientific research documents, whether they are published or not. The documents may come from teaching and research institutions in France or abroad, or from public or private research centers.
L'archive ouverte pluridisciplinaire HAL, est destinée au dépôt et à la diffusion de documents scientifiques de niveau recherche, publiés ou non, émanant des établissements d'enseignement et de recherche français ou étrangers, des laboratoires publics ou privés. 


\section{Flavonol glycosides and lignans from the leaves of Opilia amentacea}

Abdulmagid Alabdul Magid ${ }^{\mathrm{a}, *}$, Anaëlle Abdellah ${ }^{\mathrm{a}}$, Virginie Pecher ${ }^{\mathrm{b}}$, Laure Pasquier $^{\mathrm{b}}$, Dominique

Harakat $^{\mathrm{c}}$, Laurence Voutquenne-Nazabadioko ${ }^{\mathrm{a}}$

aCMR-UMR CNRS 7312, Groupe Isolement et Structure, Campus Sciences, Bât. 18, BP 1039, 51687 Reims Cedex 2, France

bLVMH recherche, département Innovation Ethnobotanique, 185 avenue de Verdun, 45800 SaintJean-de-Braye, France

'Service Commun d'Analyses, ICMR-UMR CNRS 7312, Bât. 18 B.P.1039, 51687 Reims Cedex 2, France

* Corresponding author : abdulmagid.alabdulmagid@univ-reims.fr (A. Alabdul Magid) 
Two previously undescribed flavonol tetraglycosides, isorhamnetin-3-O- $\alpha$-L-rhamnopyranosyl$(1 \rightarrow 6)-\beta$-D-galactopyranosyl-( $1 \rightarrow 4)-\alpha$-L-rhamnopyranosyl-( $1 \rightarrow 6)-\beta$-D-glucopyranoside $\quad(\mathbf{1}) \quad$ and isorhamnetin-3-O- $\alpha$-L-rhamnopyranosyl-( $1 \rightarrow 6)-\beta$-D-galactopyranosyl-( $1 \rightarrow 4)-\alpha$-Lrhamnopyranosyl-(1 $\rightarrow$ 6)- $\beta$-D-galactopyranoside $(\mathbf{2})$, along with nine known compounds including seven flavonoids and two lignans, were isolated from the leaves of Opilia amentacea Roxb (Opiliaceae). Their structures were established on the basis of spectroscopic analysis. The DPPH radical scavenging activity of compounds 1-11 was evaluated. In addition, all compounds were evaluated for their tyrosinase inhibitions by using in vitro mushroom tyrosinase assay. Only 5,5dimethoxylariciresinol-4- $O$ - $\beta$-D-glucopyranoside (10) and eleutheroside E1 (11) exhibited significant tyrosinase inhibition ( $\mathrm{IC}_{50} 42.1$ and $28 \mu \mathrm{M}$, respectively) and DPPH radical scavenging activity ( $\mathrm{IC}_{50} 85.1$ and $42.1 \mu \mathrm{M}$, respectively) compared with the positive controls. 
Keywords: Opilia amentacea, Opiliaceae, flavonoids, antioxidant activity, tyrosinase inhibitory activity.

\section{Introduction}

The genus Opilia (Opiliaceae) consists of only two species; amentacea and campestris. Opilia amentacea Roxb. (also known by its synonym O. celtidifolia Guill. \& Perr) is a West African woody climber plant, which grows in fringing forest and savannah, often on anthills (Hiepko, 2008). It is widespread from Senegal to Nigeria and dispersed over the drier parts of tropical Africa (Gronhaug et al., 2008, Togola et al., 2008). O. amentacea is a medicinal plant used by the West African traditional healers as remedy to cure a wide variety of diseases (Gronhaug et al., 2008, Hedberg et al., 1983, Sutovska et al., 2010, Togola et al., 2005). The decoction of the leaves of this plant is commonly used against skin disorders and malaria (Gronhaug et al., 2008, Sutovska et al., 2010, Togola et al., 2005), wound healing remedy (Gronhaug et al., 2008, Togola et al., 2008) and as a gargle for dental abscesses, to treat fever and oedema leprosy (Crespin et al., 1993, Gronhaug et al., 2008, Sutovska et al., 2010, Togola et al., 2005). The decoctions of root or stem are also reported against abdominal pain, internal worms (Gronhaug et al., 2008, Togola et al., 2005), as anthelmintic (Crespin et al., 1993, Hedberg et al., 1983) and appetizer (Togola et al., 2005). The root decoction is a purgative agent and is drunk in the therapy of headache (Gronhaug et al., 2008, Sutovska et al., 2010).

A review of literature showed the presence of several triterpenoid compounds such as opigenin (Druet et al., 1986), gypsogenic acid, 3 $\beta$-acetoxygypsogenic acid (Druet et al., 1991), $3 \beta$-acetoxy28 $\alpha, 20 \beta$-ursanolide (Druet et al., 1987), putranoside A, putranoside C, calenduloside F, 3-O-[ $\alpha$-Lrhamnopyranosyl-(1 $\rightarrow 3)$ - $\beta$-D-glucopyranosyl( $1 \rightarrow 2)$ - $\beta$-D-glucuronopyranosyl]-28- $O$ - $\beta$-Dglucopyranosyl-oleanate, $\quad 3-O$-[ $\alpha$-L-rhamnopyranosyl-( $1 \rightarrow 3)$ - $\beta$-D-glucuronopyranosyl $]-28-O$ - $\beta$-Dglucopyranosyl-hederagenin, $\quad 3$ - $O$-[ $\alpha$-L-rhamnopyranosyl-(1 $\rightarrow 3)-\beta$-D-xylopyranosyl-( $1 \rightarrow 2)-\beta$-Dglucuronopyranosyl]-28-O- $\beta$-D-glucopyranosyl-oleanate (Crespin et al., 1993). The pharmacological properties of saponin fractions from the plant were reported to be intestinal antispasmodic, uterine stimulant, hypotensive, and to depress the coronary outflow (Shihata et al., 1977). The carbohydrate composition of leaves O. amentacea was also studied. The main monosaccharides were found to be arabinose, galactose and galacturonic acid and with trace amount 
of rhamnose, mannose, glucose, glucuronic acid, and 4-O-methyl glucuronic acid were reported (Togola et al., 2005, Togola et al., 2008, Togola et al., 2006,). The polysaccharides were typical arabinogalactan type II which characterized by having galactose as both $\beta$-D- $(1 \rightarrow 3)$-galactose and

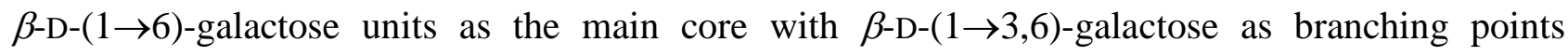
(Gronhaug et al., 2010). The polysaccharide fraction from the leaves of $O$. amentacea showed a strong human complement fixing activity in vitro and the concentration of polysaccharide fraction giving $50 \%$ of haemolysis of sheep erythrocytes were about $0.9 \mu \mathrm{g} / \mathrm{mL}$ (Togola et al., 2008). The measurement of nitric oxide released from stimulated macrophage cell line $\mathrm{R} 2(7.2 \mu \mathrm{M}$ of nitric oxide from macrophages at a dose of $100 \mu \mathrm{g} / \mathrm{mL}$ ) showed that the polysaccharide fraction had also the ability to activate macrophages (Togola et al., 2008). The polysaccharide fraction of leaves of $O$. amentacea had antitussive and bronchodilatory effects at the dose of $50 \mathrm{mg} / \mathrm{kg}$ measured by airways smooth muscle reactivity in conscious guinea pigs model (Prisenznakova et al., 2009).

Recently, the antioxidant capacities of the flavonoid-rich fractions of $O$. amentacea have been evaluated by using $\beta$-carotene-linoleate test $\left(\mathrm{IC}_{50} 70 \mu \mathrm{g} / \mathrm{mL}\right)$, DPPH radical scavenging activity $\left(\mathrm{IC}_{50} 10 \mu \mathrm{g} / \mathrm{mL}\right)$, chelation of iron (II) ions ( $\mathrm{IC}_{50} 25 \mu \mathrm{g} / \mathrm{mL}$ ), and lipid peroxidation ( $\mathrm{IC}_{50} 55 \mu \mathrm{g} / \mathrm{mL}$ ) (Konate et al., 2014), but none, to the best of our knowledge, have reported on their composition. Lack of scientific data about the phenolic contents of $O$. amentacea prompted us to this study which was therefore aimed at assessing the possible antioxidant and antityrosinase properties of polyphenol from the leaves of this plant.

Here we report the isolation and structural elucidation of two new flavonoids ( $\mathbf{1}$ and $\mathbf{2}$ ) from the ethanol extract of the leaves of $O$. amentacea, together with nine known compounds. Antioxidant activities of compounds were determined by using DPPH scavenging radical assay and their anti-tyrosinase effects were evaluated according to in vitro mushroom tyrosinase assay.

\section{Results and discussion}

The EtOH extract of $O$. amentacea leaves was subjected to VLC over RP18 to yield six fractions and the two phenol-riche fractions were purified by combination of chromatographic methods to obtain compounds 1-11 (Fig. 1). 
The sugar composition was determined by comparative TLC after acid hydrolysis of the phenols mixture as xylose (xyl), glucose (glc), galactose (gal) and rhamnose (rha) and their common D-xyl, D-glc, D-gal, or L-rha configurations were verified by measurement of the optical rotation of each purified sugar.

Compound 1 was obtained as yellow amorphous powder. The HR-ESI-MS (positive) spectrum showed an $[\mathrm{M}+\mathrm{Na}]^{+}$ion at $\mathrm{m} / \mathrm{z}$ 955.2690, indicating the molecular formula of $\mathrm{C}_{40} \mathrm{H}_{52} \mathrm{O}_{25}$. The UV spectrum showed absorption maximum at 258, 268 and $359 \mathrm{~nm}$, suggesting that 1 was a flavonoid glycoside. The ${ }^{1} \mathrm{H}$ NMR spectrum of $\mathbf{1}$ comprised resonances corresponding to aromatic and glycosidic protons, and one methoxy group. The ${ }^{13} \mathrm{C}$ NMR spectrum exhibited 40 carbon signals, including 15 aromatic carbon signals for the aglycone, one methoxyl and 24 signals for the sugar moieties. Analysis of HSQC spectrum showed correlations between protons and their corresponding carbons. The A-ring of the flavonol was represented by meta-coupled resonances at $\delta_{\mathrm{H}} 6.25(1 \mathrm{H}$, $\left.b r s, \delta_{\mathrm{C}} 100.0\right)$ and $6.50\left(1 \mathrm{H}, b r s, \delta_{\mathrm{C}} 95.1\right)$, assigned to $\mathrm{H}-6$ and $\mathrm{H}-8$, respectively. For the B-ring, the aromatic resonances at $\delta_{\mathrm{H}} 7.96\left(1 \mathrm{H}, \mathrm{d}, J=1.9 \mathrm{~Hz}, \delta_{\mathrm{C}} 114.5\right), 6.97\left(1 \mathrm{H}, \mathrm{d}, J=8.4 \mathrm{~Hz}, \delta_{\mathrm{C}} 116.3\right)$ and $7.65\left(1 \mathrm{H}, \mathrm{dd}, J=8.4,1.9 \mathrm{~Hz}, \delta_{\mathrm{C}} 124.1\right)$ were assigned to $\mathrm{H}-2^{\prime}, \mathrm{H}-5^{\prime}$ and $\mathrm{H}-6^{\prime}$, respectively. The location of the methoxy group $\left(3 \mathrm{H}, \mathrm{s}, \delta_{\mathrm{H}} 3.98, \delta_{\mathrm{C}} 56.8\right)$ was established at $\mathrm{C}-3^{\prime}$ from the correlations observed in the HMBC spectrum from $\mathrm{H}-2^{\prime}, \mathrm{H}-5^{\prime}$, and $3^{\prime}-\mathrm{OMe}$, to C-3' $\left(\delta_{\mathrm{C}} 148.4\right)$. HMBC data were also used to complete the assignment of the remaining resonances of the aglycone in the ${ }^{13} \mathrm{C}$ NMR spectrum of $\mathbf{1}$, which confirmed the presence of isorhamnetin $\left(3,5,7,4^{\prime}\right.$-tetrahydroxy-3'methoxyflavone) (Bendaikha et al., 2014). A full list of the corresponding assignments is given in Table 1. Four anomeric proton resonances corresponding to $O$-linked sugars were present in the ${ }^{1} \mathrm{H}$ NMR spectrum at $\delta_{\mathrm{H}} 4.48\left(1 \mathrm{H}, \mathrm{d}, J=7.8 \mathrm{~Hz}, \delta_{\mathrm{C}} 106.5\right), 4.54\left(1 \mathrm{H}, \mathrm{d}, J=1.4 \mathrm{~Hz}, \delta_{\mathrm{C}} 102.3\right), 4.75(1 \mathrm{H}$, $\left.\mathrm{d}, J=1.6 \mathrm{~Hz}, \delta_{\mathrm{C}} 102.2\right)$, and $5.27\left(1 \mathrm{H}, \mathrm{d}, J=7.4 \mathrm{~Hz}, \delta_{\mathrm{C}} 104.3\right)$. With the exception of two deoxyhexose methyl groups at $\delta_{\mathrm{H}} 1.15\left(3 \mathrm{H}, \mathrm{d}, J=5.7 \mathrm{~Hz}, \delta_{\mathrm{C}} 18.1\right)$ and $1.29\left(3 \mathrm{H}, \mathrm{d}, J=6.2 \mathrm{~Hz}, \delta_{\mathrm{C}}\right.$ 18.1), the remaining glycosidic proton resonances appeared between 3.29 and $3.84 \mathrm{ppm}$. Based on the results of the acid hydrolysis of flavonoids mixture, the chemical shift values, multiplicities and 
$J$-values, and the magnitudes of their $J_{1,2}$ coupling constants and the analysis of 2D NMR data, the four sugar residues were elucidated as a $\beta$-D-glucopyranose $(\mathrm{glc})\left(\delta_{\mathrm{H}-1} 5.27\right)$, a $\beta$-D-galactopyranose (gal) $\left(\delta_{\mathrm{H}-1} 4.48\right)$, and two $\alpha$-L-rhamnopyranose residues: rha-I $\left(\delta_{\mathrm{H}-1} 4.54\right)$ and rha-II $\left(\delta_{\mathrm{H}-1} 4.75\right)$ (Table 1). The $\beta$-D-glc was characterized by large coupling constants $\left(J_{\mathrm{H}-1, \mathrm{H}-2}, J_{\mathrm{H}-2, \mathrm{H}-3}, J_{\mathrm{H}-3, \mathrm{H}-4}, J_{\mathrm{H}-}\right.$ 4,H-5 $\geq 7.4 \mathrm{~Hz}$ ), the $\beta$-D-gal was characterized by the large coupling constants $J_{\mathrm{H}-1, \mathrm{H}-2}$ and $J_{\mathrm{H}-2, \mathrm{H}-3}(>$ $7.8 \mathrm{~Hz}$ ) and the small coupling constant $J_{\mathrm{H}-3, \mathrm{H}-4}(3.4 \mathrm{~Hz})$. These two hexoses were substituted at C-6 position as suggested by the downfield-shifted C- 6 of glc at $\delta_{\mathrm{C}} 68.4$ and C- 6 of gal at $\delta_{\mathrm{C}} 67.9$. The two $\alpha$-L-rha units (rha-I and rha-II) were characterized by the small coupling constants $J_{\mathrm{H}-1, \mathrm{H}-2}(1.4$ $\mathrm{Hz}$ ) and theirs methyl groups, the first was substituted in position 4 as suggested by its downfieldshifted C-4 ( $\left.\delta_{\mathrm{C}-4} 83.8\right)$ and the second was in a terminal position (Table 1). A correlation between $\mathrm{H}-1$ of glc and $\delta_{\mathrm{C}} 135.4$ in the HMBC spectrum of $\mathbf{1}$ defined C-3 as the site of $O$-glycosylation. The interglycosidic linkages of the tetrasaccharide moiety were also determined by HMBC analysis. Correlations from $\mathrm{H}-1$ of rha-I to C-6 of glc $\left(\delta_{\mathrm{C}} 68.4\right)$ indicated that the rha-I residue was 6-Olinked to glc. Similarly, correlations from H-4 of rha-I to C-1 of gal, and reversely from H-1 of gal to C-4 of rha-I at $\delta_{\mathrm{C}} 83.8$, and from H-6 of gal and C-1 of rha-II and reversely from $\mathrm{H}-1$ of rha-II to C-6 of gal $\left(\delta_{\mathrm{C}} 67.9\right)$ indicated that the gal residue was 4- $O$-linked to rha-I and 6- $O$-substituted by rha-II. Thus, the structure of $\mathbf{1}$ was determined to be isorhamnetin-3- $O-\alpha$-L-rhamnopyranosyl$(1 \rightarrow 6)-\beta$-D-galactopyranosyl-( $1 \rightarrow 4)-\alpha$-L-rhamnopyranosyl-( $1 \rightarrow 6)-\beta$-D-glucopyranoside. Compounds 2 and 1 had the same molecular formula $\mathrm{C}_{40} \mathrm{H}_{52} \mathrm{O}_{25}$ (HR-ESI-MS, $m / z$ 955.2695 [M + $\mathrm{Na}]^{+}$). The ${ }^{1} \mathrm{H}$ and ${ }^{13} \mathrm{C}$ NMR signals of the aglycone and the saccharide parts of 2 , assigned from 1D and 2D NMR spectra analysis, were almost superimposable to those of $\mathbf{1}$ except for signals corresponding to the glucose moiety (Table 1). A $\beta$-D-galactopyranose (gal-I), instead a $\beta$-Dglucopyranose, was observed starting from the anomeric proton at $\delta_{\mathrm{H}} 5.23\left(1 \mathrm{H}, \mathrm{d}, J=7.7 \mathrm{~Hz}, \delta_{\mathrm{C}}\right.$ 105.0), characterized by its equatorial proton $\mathrm{H}-4$ at $\delta_{\mathrm{H}} 3.79\left(\mathrm{~d}, J_{\mathrm{H}-3, \mathrm{H}-4}=3.3 \mathrm{~Hz}\right.$ ) (Table 1$)$. The complete assignment of the NMR spectra of $\mathbf{2}$ was achieved in a similar fashion to $\mathbf{1}$. Correlations detected in the HMBC spectrum of $\mathbf{2}$ confirmed that its structure was identical to that of $\mathbf{1}$, except 
that glc unit was replaced by a gal-I residue. Thus 2 was isorhamnetin-3- $O$ - $\alpha$-L-rhamnopyranosyl$(1 \rightarrow 6)-\beta$-D-galactopyranosyl-( $1 \rightarrow 4)$ - $\alpha$-L-rhamnopyranosyl-( $1 \rightarrow 6)-\beta$-D-galactopyranoside.

The known compounds 3-11 were identified from this species for the first time and their structural assignments were made by ESI-MS and 1D, and 2D NMR analysis. Their spectroscopic data were in perfect agreement with those reported in the literature for isorhamnetin-3-O- $\alpha$-L-

rhamnopyranosyl-(1 $\rightarrow$ 6)- $\beta$-D-galactopyranoside (3) (Buschi and Pomilio, 1982), kaempferol-3-O$\alpha$-L-rhamnopyranosyl-(1 $\rightarrow 6$ )- $\beta$-D-galactopyranoside (4) (Yasukawa and Takido, 1982), isorhamnetin-3- $O$ - $\alpha$-L-rhamnopyranosyl-(1 $\rightarrow 6)-\beta$-D-glucopyranoside (5) (Bennini, Chulia, 1994), kaempferol-3- $O$ - $\beta$-D-apiofuanosyl-( $1 \rightarrow 2)$-[ $\alpha$-L-rhamnopyranosyl-( $1 \rightarrow 6)]-\beta$-D-glucopyranoside $(\mathbf{6})$ (Dini et al., 2004), kaempferol-3- $O$ - $\alpha$-L-rhamnopyranosyl-(1 $\rightarrow 6)-\beta$-D-glucopyranoside (7)

(Pawlowska et al., 2009), kaempferol-3-O-(2,6- $\alpha$-L-dirhamnopyranosyl)- $\beta$-D-glucopyranoside (8) (Kazuma et al., 2003), kaempferol-3-O- $\beta$-D-glucopyranoside (9) (Lee et al., 2012), 5,5-

dimethoxylariciresinol-4-O- $\beta$-D-glucopyranoside (10) (Ida et al., 1993), and (+) syringaresinol-4'$O$ - $\beta$-D-glucopyranoside also named eleutheroside E1 (11) (Shahat et al., 2004).

The flavonoid-rich fraction of $O$. amentacea was reported to possess antioxidant activities and the use of this plant as a wound healing remedy or to treat skin disorders were also mentioned. Thus, EtOH 70\% extract was tested for their tyrosinase inhibitory and DPPH free radical scavenging activities. The EtOH $70 \%$ from $O$. amentacea exhibited moderate to low scavenging effect on DPPH radicals ( IC $_{50} 250 \mu \mathrm{g} / \mathrm{mL}$ ) and fungal tyrosinase inhibitory activity ( $\mathrm{IC}_{50} 509 \mu \mathrm{g} / \mathrm{mL}$ ) (Table 2). To identify the compounds responsible for the observed activities, this extract was subjected to vacuum liquid chromatography over RP-18 to obtain six fractions $\mathrm{A}_{1}-\mathrm{A}_{6}$. Only fraction $\mathrm{A}_{3}$ showed moderate DPPH scavenging ( $\mathrm{IC}_{50} 200 \mu \mathrm{g} / \mathrm{mL}$ ) and fungal tyrosinase inhibitory activities ( IC $_{50} 326$ $\mu \mathrm{g} / \mathrm{mL}$ ) (Table 2). Fraction $\mathrm{A}_{3}$ was purified by combination of chromatographic methods to obtain compounds 1-11. Only compounds $\mathbf{1 0}$ and $\mathbf{1 1}$ exhibited good tyrosinase inhibitory effect ( $\mathrm{IC}_{50} 42.1$ and $28 \mu \mathrm{M}$, respectively), compared to the reference kojic acid ( $\left.\mathrm{IC}_{50} 45.98 \mu \mathrm{M}\right)$. Compounds $\mathbf{1 0}$ and 11 showed also good inhibitory effect on DPPH assay ( $\mathrm{IC}_{50} 85.1$ and $42.1 \mu \mathrm{M}$, respectively), 
compared to ascorbic acid ( $\left.\mathrm{IC}_{50} 56.8 \mu \mathrm{M}\right)$. It is interesting that the two lignans (10-11) have bifunctionality, not just containing the antioxidant activity, but also had a tyrosinase inhibitory effect. The findings could enrich the flavonoids diversity and be regarded as some further insight into the chemotaxonomic diversity of natural products in Opilia. Compound $\mathbf{1 1}$ was previously reported to possess an antioxidant activity [DPPH, ABTS and FRAP assays, $\mathrm{IC}_{50} 104.2,18$, and $73.5 \mu \mathrm{g} / \mathrm{mL}$, respectively (Huang et al., 2016), DPPH assay $\mathrm{IC}_{50} 37.03 \mu \mathrm{g} / \mathrm{mL}$ ou $\mu \mathrm{M}$ ? (Zaluski et al., 2017), ORAC assay $2.03 \mu \mathrm{M}$, (Zhou et al., 2017)]. The anti-neuroinflammatory effect of compound 10 was tested in BV2 microglial cells by measurement of NO production in LPS-induced ( IC $_{50} 3.08$ $\mu \mathrm{M})$ (Li et al., 2016). Non available data were found about the bioactivities of compound 10. HPLC analysis of the $\mathrm{EtOH} 70 \%$ from $O$. amentacea indicated that the major components were compounds 4 (1.94\%) and 5. The analytical HPLC chromatograms of fractions $\mathrm{A}_{1}-\mathrm{A}_{6}$ indicated that compounds $\mathbf{1 0}$ and $\mathbf{1 1}$ were the major components in fraction $\mathrm{A}_{3}$ whereas compounds $\mathbf{4}$ and $\mathbf{5}$ were the major compounds in fraction $\mathrm{A}_{4}$. HPLC analysis of fraction $\mathrm{A}_{5}$ as described by Crespin et al. (1993a) revealed the presence of the six saponins previously characterized in this plant (Crespin et al., 1993b).

\section{Experimental}

\subsection{Reagents and materials}

Mushroom tyrosinase, ascorbic acid, dimethyl sulfoxide (DMSO), kojic acid, L-tyrosine, and 1,1diphenyl-2-picrylhydrazyl (DPPH) were purchased from Sigma-Aldrich (Germany). All buffers and other reagents were of the highest purity commercially available.

\subsection{General experimental procedures}

Optical rotations were determined in $\mathrm{MeOH}$ with a Perkin-Elmer 341 polarimeter. UV spectra were obtained in $\mathrm{MeOH}$, using a Shimadzu UV-2450 spectrophotometer. Absorbance (Ab) values in the biological assays were read on a Fluostar omega microplate reader (BMG labtech). NMR spectra were carried in $\mathrm{MeOH}-d_{4}$ on Bruker Avance DRX III 500 instruments $\left({ }^{1} \mathrm{H}\right.$ at $500 \mathrm{MHz}$ and ${ }^{13} \mathrm{C}$ at $125 \mathrm{MHz})$. Standard pulse sequences and parameters were used to obtain $1 \mathrm{D}\left({ }^{1} \mathrm{H}\right.$ and $\left.{ }^{13} \mathrm{C}\right)$ and $2 \mathrm{D}$ 
(COSY, HSQC, and HMBC) spectra. HR-ESI-MS were measured on a Micromass Q-TOF micro instrument (Manchester, UK). Silica gel 60 (Merck, 63-200 mesh) or LiChroprep RP-18 (40-63 $\mu \mathrm{m})$ Merck were used for column chromatography. Precoated silica gel plates (Merck, Kieselgel 60 $\mathrm{F}_{254}, 0.20 \mathrm{~mm}$ ) were used for analytical TLC and spots were detected under UV light at 254 and 365 $\mathrm{nm}$ and visualized by spraying the dried plates with $50 \% \mathrm{H}_{2} \mathrm{SO}_{4}$, followed by heating. Flash chromatography was performed on a Grace Reveleris system with dual UV and ELSD detection equipped with a $12 \mathrm{~g}$ RP-C 18 column. The mobile phase was water and methanol with a flow rate of $30 \mathrm{~mL} / \mathrm{min}$ and the effluents were monitored at 205 and $254 \mathrm{~nm}$. HPLC was performed on a Dionex apparatus equipped with an ASI-100 autosampler, an Ultimate 3000 pump, a diode array detector UVD 340S and Chromeleon software. $\mathrm{C}_{18}$ reversed phase column (Phenomenex 250 x $10 \mathrm{~mm}$, Luna $5 \mu$ ) was used for semi preparative HPLC with binary gradient eluent $\left(\mathrm{H}_{2} \mathrm{O}(\mathrm{pH} 2.4\right.$ with TFA); $\mathrm{MeCN}$ ) and a flow rate of $5 \mathrm{~mL} \cdot \mathrm{min}^{-1}$; the chromatogram was monitored at 205, 210, 250, and 360 nm. An RP18 column (Phenomenex $250 \times 4.6 \mathrm{~mm}$, Luna $5 \mu$ ) was used for analytical HPLC with binary gradient eluent $\left(\mathrm{H}_{2} \mathrm{O}\left(\mathrm{pH} 2.4\right.\right.$ with TFA); $\left.\mathrm{CH}_{3} \mathrm{CN}\right)$ and a flow rate of $1 \mathrm{~mL} \cdot \mathrm{min}^{-1}$. The analytical HPLC of the EtOH $70 \%$ and fractions $\mathrm{A}_{1}-\mathrm{A}_{6}$ of Opilia amentacea was achieved using the gradient program: $10 \%$ to $33 \%$ (in $30 \mathrm{~min}$ ), $33 \%$ (for $30 \mathrm{~min}$ ) $\mathrm{CH}_{3} \mathrm{CN}$ in $0.0025 \%$ TFA. The chromatogram was monitored at a wavelength of $205 \mathrm{~nm}$ during the experiment. The column temperature was maintained at $30{ }^{\circ} \mathrm{C}$ and the injection volume of sample solution $(5 \mathrm{mg} / \mathrm{mL})$ was $15 \mu \mathrm{L}$.

\subsection{Extraction and isolation}

The EtOH extract of leaves of Opilia amentacea Roxb. was provided by LVMH Recherche (Lot 14/045-cahier HB). The EtOH extract (10 g) was subjected to vacuum liquid chromatography (VLC) over RP-18 (9 x 5 cm) eluted successively with $\mathrm{MeOH}-\mathrm{H}_{2} \mathrm{O}(0: 10,2: 8,4: 6,6: 4,8: 2$, and 10:0) to give six fractions $\left(\mathrm{A}_{1}-\mathrm{A}_{6}\right.$, respectively). Fraction $\mathrm{A}_{3}(2.7 \mathrm{~g})$ was applied to a silica gel VLC and eluted with $\mathrm{CHCl}_{3}-\mathrm{MeOH}$ gradually enriched with $\mathrm{H}_{2} \mathrm{O}$ to afford 7 fractions. Fraction 1 (240 mg) eluted with $\mathrm{CHCl}_{3}-\mathrm{MeOH}(8: 2)$ was further purified by silica gel flash chromatography eluted with a gradient system of $\mathrm{CHCl}_{3}-\mathrm{MeOH}(10: 0-9: 1$ in $20 \mathrm{~min})$ to afford 130 fractions. Frs [26-55] 
(21 mg) were purified by semi-prep HPLC eluted with a gradient system of $20-30 \%$ of MeCN in 20 min to afford compound 11 (Rt $15.8 \mathrm{~min}, 4 \mathrm{mg}$ ). Frs [79-87] (48 mg) were purified by semi-prep HPLC eluted with a gradient system of $20-30 \%$ of MeCN in 20 min to afford compounds $\mathbf{1 0}$ ( $R t$ $11.6 \mathrm{~min}, 3 \mathrm{mg}$ ) and 9 (Rt $14.8 \mathrm{~min}, 2 \mathrm{mg})$. Fraction 2 (700 mg) eluted with $\mathrm{CHCl}_{3}-\mathrm{MeOH}(7: 3)$ was further purified by silica gel flash chromatography eluted with a gradient system of $\mathrm{CHCl}_{3-}$ $\mathrm{MeOH}(9: 1-7: 3$ in $35 \mathrm{~min})$ to afford 130 fractions. Frs [55-59] (47 mg) were purified by semi-prep HPLC in isocratic elution with $20 \%$ of $\mathrm{MeCN}$ for $25 \mathrm{~min}$ to afford compounds $\mathbf{3}$ (Rt $20.0 \mathrm{~min}, 8$ $\mathrm{mg}$ ), 4 (Rt $22.9 \mathrm{~min}, 32 \mathrm{mg}$ ), and 5 (Rt $24.4 \mathrm{~min}, 13 \mathrm{mg}$ ). Frs [87-99] (54 mg) were purified by semi-prep HPLC in isocratic elution with $18 \%$ of $\mathrm{MeCN}$ for 25 min to afford compounds 6 (Rt 20.9 min, $4 \mathrm{mg}$ ) and 7 (Rt $22.0 \mathrm{~min}, 7 \mathrm{mg}$ ). Frs [104-130] (30 mg) were purified by semi-prep HPLC in isocratic elution with $18 \%$ of $\mathrm{MeCN}$ for $35 \mathrm{~min}$ to afford compounds $\mathbf{8}$ ( $R t 18.9 \mathrm{~min}, 2 \mathrm{mg}), \mathbf{1}(R t$ $26.6 \mathrm{~min}, 3 \mathrm{mg}$ ), and 2 (Rt $28.5 \mathrm{~min}, 4 \mathrm{mg}$ ).

\subsubsection{Isorhamnetin-3-O- $\alpha$-L-rhamnopyranosyl-( $1 \rightarrow 6)-\beta$-D-galactopyranosyl-( $(1 \rightarrow 4)-\alpha-L-$}

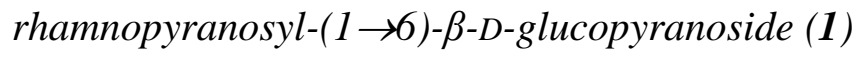
$[\alpha]^{20} \mathrm{D}-48.0(c 0.1, \mathrm{MeOH}) ; \mathrm{UV}(\mathrm{MeOH}) \lambda_{\max } \mathrm{nm}: 258,268,359 ;{ }^{1} \mathrm{H}$ and ${ }^{13} \mathrm{C} \mathrm{NMR}\left(\mathrm{MeOH}-d_{4}\right)$ spectroscopic data, see Table 1; HR-ESI-MS m/z: $955.2690[\mathrm{M}+\mathrm{Na}]^{+}\left(\right.$calcd for $\mathrm{C}_{40} \mathrm{H}_{52} \mathrm{O}_{25} \mathrm{Na}$, 955.2695).

\subsubsection{Isorhamnetin-3-O- $\alpha$-L-rhamnopyranosyl-( $1 \rightarrow 6)-\beta$-D-galactopyranosyl-( $(1 \rightarrow 4)-\alpha-L$ -} rhamnopyranosyl-(1 $\rightarrow 6)-\beta$-D-galactopyranoside (2) $[\alpha]^{20}{ }_{\mathrm{D}}-45.1\left(c\right.$ 0.1, MeOH); UV $(\mathrm{MeOH}) \lambda_{\max } \mathrm{nm}: 255,269,357 ;{ }^{1} \mathrm{H}$ and ${ }^{13} \mathrm{C} \mathrm{NMR}\left(\mathrm{MeOH}-d_{4}\right)$ spectroscopic data, see Table 1; HR-ESI-MS m/z: $955.2690[\mathrm{M}+\mathrm{Na}]^{+}\left(\right.$calcd for $\mathrm{C}_{40} \mathrm{H}_{52} \mathrm{O}_{25} \mathrm{Na}$, 955.2695).

\subsection{Acid hydrolysis}

The acid hydrolysis was realized as previously described (Alabdul Magid et al., 2015). Briefly, 200 $\mathrm{mg}$ of the flavonoids riche fraction (fraction $\mathrm{A}_{3}$ ) was refluxed with $20 \mathrm{~mL}$ of $2 \mathrm{M}$ TFA for $3 \mathrm{~h}$. After extraction with ethyl acetate $(3 \times 15 \mathrm{~mL})$, the aqueous layer was evaporated to furnish the 
monosaccharide residue $(160 \mathrm{mg})$. Four sugars were identified as D-apiose, D-glucose, D-galactose and L-rhamnose by comparison with authentic samples on TLC and by measurement of the optical rotation of each purified sugar.

\subsection{Free radicals scavenging activity}

The antioxidant activity of our target compound was measured in terms of hydrogen donating or radical scavenging ability using the stable DPPH method (Benmerache et al., 2016). Briefly, $5 \mu \mathrm{L}$ of different concentrations of the samples (dissolved in DMSO) were added to $95 \mu \mathrm{L}$ of DPPH solution $(158 \mu \mathrm{M}$, dissolved in $\mathrm{EtOH} 50 \%)$. The reaction proceeded for $30 \mathrm{~min}$ at $37{ }^{\circ} \mathrm{C}$ on a 96 well microplate. The absorbance was then read at $\lambda 515 \mathrm{~nm}$. The percentage of inhibition was calculated using the following equation: \% inhibition $\left[\left(\mathrm{Ab}_{\text {control }}-\mathrm{A} \mathrm{b}_{\text {sample }}\right) / \mathrm{A} \mathrm{b}_{\text {control }}\right] \times 100$. DPPH solution in EtOH was used as a control. The curve of the \% scavenging activity against the concentration of sample was prepared by MSExcel based program to obtain the $\mathrm{EC}_{50}$ (concentration required to obtain a $50 \%$ antioxidant effect). All the tests were conducted in triplicate. The experimental data were expressed as mean \pm standard deviation. Ascorbic acid was used as a positive control agent.

\subsection{Tyrosinase enzyme assay}

Tyrosinase activity inhibition was determined spectrophotometrically according to the method described previously (Benmerache et al., 2016). Different concentrations of test compounds were prepared in $10 \%$ DMSO in aqueous solution and $100 \mu \mathrm{L}$ of each concentration were added to 96well plate and then $100 \mu \mathrm{L}$ of $135 \mathrm{U} / \mathrm{mL}$ mushroom tyrosinase in phosphate buffer solution (PBS, pH 6.8) were added. After pre-incubation at $25^{\circ} \mathrm{C}$ for $10 \mathrm{~min}, 100 \mu \mathrm{L}$ of L-dopa (0.5 mM, PBS pH 6.8) were added into 96 -well plate. The reaction mixture was incubated for another 5 min at $25^{\circ} \mathrm{C}$. The amount of dopachrome in the mixture was determined by the measurement of the absorbance of each well at $475 \mathrm{~nm}$. Kojic acid was used as positive control agent. The inhibitory percentage of tyrosinase was calculated according to the following equation: \% inhibition $=\{[(A-B)-(C-D)] /(A$ - B) $\} \times 100(A$ : Ab at $475 \mathrm{~nm}$ without test substance; $B:$ Ab at $475 \mathrm{~nm}$ without test substance and 
tyrosinase; $C$ : Ab at $475 \mathrm{~nm}$ with test substance; $D: \mathrm{Ab}$ at $475 \mathrm{~nm}$ with test substance, but without tyrosinase). All the tests were conducted in triplicate and $\mathrm{IC}_{50}$ was determined by interpolation of concentration \% inhibition curve obtained by MSExcel based program. The experimental data were expressed as mean \pm standard deviation.

Conflict of interest: The authors declare no conflict of interest.

Supplementary data: HR-ESIMS and NMR data for compound 1 and 2 and HPLC chromatographic profiles of the $70 \%$ EtOH extract and fractions $A_{1}-A_{6}$.

\section{Acknowledgments}

The authors are grateful to CNRS, Conseil Régional Champagne Ardenne, Conseil Général de la Marne, and Ministry of Higher Education and Research (MESR), the PIANET CPER project, and to LVMH recherche for financial support.

\section{References}

Alabdul Magid, A., Morjani, H., Harakat, D., Madoulet, M., Dumontet, V., Lavaud, C., 2015. Triterpenoid glycosides from the leaves of Meliosma henryi. Phytochemistry 109, 49-56.

Bendaikha, S., Gadaut, M., Harakat, D., Alabdul Magid, A., 2014. Acylated flavonol glycosides from the flower of Elaeagnus angustifolia L. Phytochemistry 103, 129-136.

Benmerache, A., Alabdul Magid, A., Berrehal, D., Kabouche, A., Voutquenne-Nazabadioko, A., Messaili, A., Abedini, A., Harakat, A., Kabouche, Z., 2016. Chemical composition, antibacterial, antioxidant and tyrosinase inhibitory activities of glycosides from aerial parts of Eryngium tricuspidatum L. Phytochem. Lett. 18, 23-28.

Bennini, B., Chulia, A.J., 1994. Flavonol glycosides from Erica cinerea. J. Nat. Prod. 57, 178-180. Buschi, C.A., Pomilio, A.B., 1982. Isorhamnetin 3-O-robinobioside from Gomphrena martiana. J. Nat. Prod. 45, 557-559. 
Crespin, F., Oliver, E., Elias, R., Maillard, C., Balansard, G., 1993. High-performance liquid chromatographie determination of the major saponin from Opilia celtidifolia Guill. Perr. J. Chromatogr. 644, 404-406 (a), Crespin, F., Oliver, E., Lavaud, C., Babadjamian, A., Faure, R., Debrauwer, L., Balansard, G., Boudon, G., 1993. Triterpenoid saponins from Opilia celtidifolia. Phytochemistry 33, 657-661 (b).

Dini, I., Tenore, G.C., Dini, A., 2004. Phenolic constituents of Kancolla seeds. Food Chem. 84,163168.

Druet, D., Comeau, L., Zahra, J.P., 1986. Structure de l'opigénine: triterpène pentacyclique isolé d'Opilai celtidifolia. Can. J. Chem. 64, 295-299.

Druet, D., Comeau, L.C., Estienne, J., 1991. Isolation of an aglycon from Opilia celtidifolia: $3 \beta$ acetoxyolean-12-ene-23 $\alpha, 28 \beta$-dioic acid. Planta med. 57, 200.

Druet, D., Comeau, L.C., Viani, R., Baldy, A., Estienne, J., Pierrot, M.,1987. Crystal and molecular structure of $3 \beta$-acetoxy-28 $\alpha, 20 \beta$-ursanolide. Can. J. Chem. $65,851-854$.

Gronhaug, T.E., Glaeserud, S., Skogsrud, M., Ballo, N., Bah, S., Diallo, D., Paulsen, B.S., 2008. Ethnopharmacological survey of six medicinal plants from Mali. West Africa. J. Ethnopharmacol. 4, 4-26.

Gronhaug, T.E., Ghildyal, P., Barsett, H., Michaelsen, T.E., Morris, G., Diallo, D., Inngjerdingen, M., Paulsen, B.S., 2010. Bioactive arabinogalactans from the leaves of Opilia celtidifolia Endl. ex Walp. (Opiliaceae). Glycobiology 20, 1654-1664.

Hedberg, I., Hedberg, O., Madati, P.J., Mshigeni, K.E., Mshiu, E.N., Samuelsson, G., 1983. Inventory of plants used in traditional medicine in Tanzania. II. Plants of the families Dilleniaceae to Opiliaceae. J. Ethnopharmacol. 9, 105-128.

Hiepko, P., 2008. Species plantarum: flora of the world. Part 12, Opiliaceae,1-71. Ed: Genève : Conservatoire et jardin botaniques de la ville de Genève (Geneva, Switzerland). 
Huang, S.W., Qiao, J.W., Sun, X., Gao, P.Y., Li, L.Z., Liu, Q.B., Sun, B., Wu, D.L., Song, S.J., 2016. Secoiridoids and lignans from the leaves of Diospyros kaki Thunb. With antioxidant and neuroprotective activities. J. Fonct. Foods. 24, 183-195.

Ida, Y., Datoh, Y., Ohtsuka, M., Nagasao, M., Shoji, J., 1993. Phenolic constituents of phellodendron amurense bark. Phytochemistry 35, 209-215.

Kazuma, K., Noda, N., Suzuki, M., 2003. Malonylated flavonol glycosides from the petals of Clitoria ternatea.Phytochemistry 62, 229-237.

Konate, K., Yomalan, K., Sytar, O., Zerbo, P., Brestic, M., Patrick, V.D., Gagniuc, P., Barro, N., 2014. Free radicals scavenging capacity, antidiabetic and antihypertensive activities of flavonoid-rich fractions from leaves of Trichilia emetic and Opilia amentacea in an animal model of type 2 diabetes Mellitus. Evid. Based Complement Alternat. Med. 2014, 867075.

Lee, S.Y., Kim, J.S., Kang, S., 2012. Flavonol glycosides from the aerial parts of Metaplexis japonica. Kor. J. Pharmacogn. 43, 206-2012.

Li, N., Wang, Y., Li, X., Zhang, H., Zhou, D., Wang, W., Li, W., Zhang, X., Li, X., Hou, Y., Meng, D., 2016. Bioactive phenols as potential neuroinflammation inhibitors from the leaves of Xanthoceras sorbifolia Bunge. Bioorg. Med. Chem. Lett. 26, 5018-5023.

Pawlowska, A.M., Camangi, F., Bader, A., Braca, A., 2009. Flavonoids of Zizyphus jujube L. and Zizyphus spina-christi (L) Wild (Rhamnaceae) fruits. Food Chem. 112, 858-862.

Prisenznakova, L., Sutovska, M., Nosalova, G., Franova, S., Joskova, M., Capek, P., 2009. Antitussive active herbal polysaccharides isolated from Malian medicinal plants Trichilia emetica Vahl. (Meliaceae), and Opilia celtidifolia Guill. \& Perr. Endl. ex Walp. (Opiliaceae). Acta. Medica. Martiniana 9, 18-24.

Shahat, A.A., Abdel-Azim, N.S., Pieters, L., Vlietinck, A.J., 2004. Isolation and NMR spectra of syringaresinol- $\beta$-D-glucoside from Cressa cretica. Fitoterapia 75, 771-773.

Shihata, I.M., El-Gendi, A.Y., Abd El-Malik, M.M., 1977. Pharmacochemical studies on saponin fraction of Opilia celtidifolia. Planta med. 31, 60-67. 
Sutovska, M., Franova, S., Sadlonova, V., Gronhaug, T.E., Diallo, D., Paulsen, B.S., Capek, P., 2010. The relationship between dose-dependent antitussive and bronchodilatory effects of Opilia celtidifolia polysaccharide and nitric oxide in guinea pigs. Int. J. Biol. Macromol. 47, $508-513$.

Togola, A., Diallo, D., Dembélé, S., Barsett, H., Paulsen, B.S., 2005. Ethnopharmacological survey of different uses of seven medicinal plants from Mali, (West Africa) in the regions Doila, Kolokani and Siby. J. Ethnobiol. Ethnomed. 1, 7-16.

Togola, A., Diallo, D., Michaelsen, T.E., Paulsen, B.S., 2006. Structure elucidation of bioactive pectins from Opilia celtidifolia (Guill. \& Perr.) Endl. Ex Walp. (Opiliaceae). Planta Med. 72, 67.

Togola, A., Inngjerdingen, M., Diallo, D., Barsett, H., Rolstad, B., Michaelsen, T.E., Paulsen, B.S., 2008. Polysaccharides with complement fixing and macrophage stimulation activity from Opilia celtidifolia, isolation and partial characterization. J. Ethnopharmacol.115, 423-431.

Yasukawa, K., Takido, M., 1987. A flavonol glycoside from Lysimachia Mauritiana. Phytochemistry 26, 1224-1226.

Zaluski, D., Kuz'niewski, Rafal, Janeczko, Z., 2017. HPTLC-profiling of eleutherosides, mechanism of antioxidative action of eleutheroside E1, the PAMPA test with LC/MS detection and the structure-activity relationship. Saudi. J. Biol. Sci. https://doi.org/10.1016/j.sjbs.2016.01.018.

Zhou, Z.Q., Xiao, J., Fan, H.X., Yu, Y., He, R.R., Feng, X.L., Kurihara, H., So, K.F., Yao, X.S., Gao, H., 2017. Polyphenols from wolfberry and their bioactivities. Food Chem. 214, 644654. 


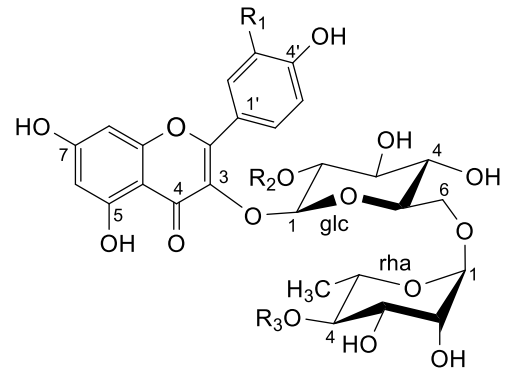

$\begin{array}{ccc}\mathbf{R}_{\mathbf{1}} & \mathbf{R}_{\mathbf{2}} & \mathbf{R}_{\mathbf{3}} \\ \mathbf{1 :}: \mathrm{OCH}_{3} & \mathrm{H} & \text { rha- }(1 \rightarrow 6) \text {-gal- }\end{array}$

$\mathbf{5}: \mathrm{OCH}_{3} \quad \mathrm{H} \quad \mathrm{H}$

7: $\mathrm{H} \quad \mathrm{H} \quad \mathrm{H}$

8: $\mathrm{H}$ api

(c)

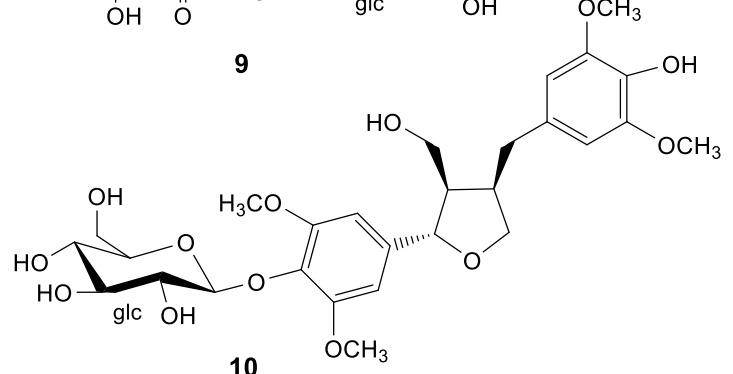

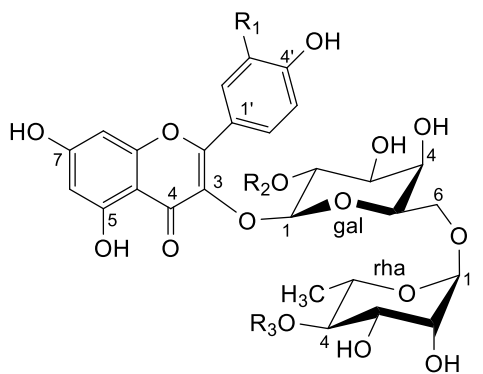

$\begin{array}{lll}\mathbf{R}_{\mathbf{1}} & \mathbf{R}_{\mathbf{2}} & \mathbf{R}_{\mathbf{3}}\end{array}$

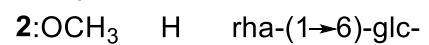

3: $\mathrm{OCH}_{3} \quad \mathrm{H}$

4: $\mathrm{H} \quad \mathrm{H}$

6: $\mathrm{H}$ api

$\mathrm{H}$

api $=$ apiofuanosyl
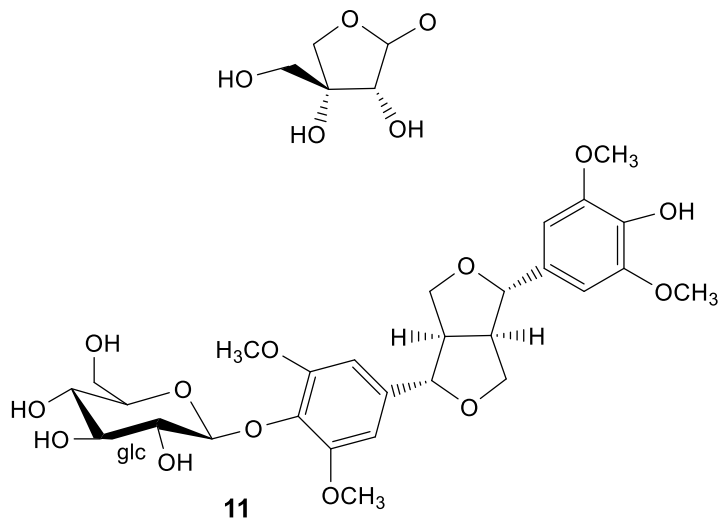

Fig.1. Chemical structures of compounds 1- 11, isolated from O. amentacea. 
Table 1. ${ }^{1} \mathrm{H}$ and ${ }^{13} \mathrm{C}$ spectroscopic data for compounds 1 and $2\left(\mathrm{MeOH}-d_{4}, 500 / 125 \mathrm{MHz}\right)$.

\begin{tabular}{|c|c|c|c|c|c|c|c|c|c|}
\hline & 1 & & 2 & & & 1 & & 2 & \\
\hline Aglycone & $\delta_{\mathrm{H}} \mathrm{m}\left(J_{\mathrm{Hz}}\right)$ & $\delta_{\mathrm{C}}$ & $\delta_{\mathrm{H}} \mathrm{m}\left(J_{\mathrm{Hz}}\right)$ & $\delta_{\mathrm{C}}$ & Sugars & $\delta_{\mathrm{H}} \mathrm{m}\left(J_{\mathrm{Hz}}\right)$ & $\delta_{\mathrm{C}}$ & $\delta_{\mathrm{H}} \mathrm{m}\left(J_{\mathrm{Hz}}\right)$ & $\delta_{\mathrm{C}}$ \\
\hline 2 & - & 158.8 & - & 158.9 & & glc & & gal & \\
\hline 3 & - & 135.4 & - & 135.5 & 1 & $5.27 \mathrm{~d}(7.4)$ & 104.3 & $5.23 \mathrm{~d}(7.7)$ & 105.0 \\
\hline 4 & - & 179.5 & - & 179.5 & 2 & $3.48 \mathrm{dd}(8.6,7.4)$ & 75.9 & 3.84 dd $(8.3,7.7)$ & 73.1 \\
\hline 5 & - & 163.0 & - & 163.0 & 3 & $3.37 \mathrm{t}(8.6)$ & 77.3 & 3.60 dd $(8.3,3.3)$ & 75.0 \\
\hline 6 & $6.25 \mathrm{brs}$ & 100.0 & $6.25 \mathrm{brs}$ & 100.0 & 4 & $3.29 \mathrm{t}(8.6)$ & 71.5 & $3.79 \mathrm{~d}(3.3)$ & 70.1 \\
\hline 7 & - & 166.0 & - & 166.0 & 5 & $3.45 \mathrm{~m}$ & 78.2 & $3.67 \mathrm{~m}$ & 75.4 \\
\hline 8 & $6.50 \mathrm{brs}$ & 95.1 & $6.47 \mathrm{brs}$ & 95.0 & 6 & $3.50 \mathrm{~m}$ & 68.4 & $3.47 \mathrm{dd}(11.5,2.2)$ & 67.6 \\
\hline 9 & - & 158.5 & - & 158.5 & & $3.82 \mathrm{dd}(12.5,3.2)$ & & $3.75 \mathrm{dd}(11.5,5.6)$ & \\
\hline 10 & - & 105.7 & - & 105.7 & rha-I & & & & \\
\hline $1^{\prime}$ & - & 123.1 & - & 123.0 & 1 & $4.54 \mathrm{~d}(1.4)$ & 102.3 & $4.54 b r s$ & 101.8 \\
\hline $2^{\prime}$ & $7.96 \mathrm{~d}(1.9)$ & 114.5 & $8.05 \mathrm{~d}(2.1)$ & 114.6 & 2 & $3.67 \mathrm{dd}(3.3,1.4)$ & 71.5 & $3.64 \mathrm{dd}(3.3,1.1)$ & 72.0 \\
\hline $3^{\prime}$ & - & 148.4 & - & 148.4 & 3 & $3.71 \mathrm{dd}(9.1,3.3)$ & 72.4 & $3.75 \mathrm{dd}(8.5,3.3)$ & 72.3 \\
\hline $4^{\prime}$ & - & 150.9 & - & 150.9 & 4 & $3.50 \mathrm{t}(9.1)$ & 83.8 & $3.50 \mathrm{t}(8.5)$ & 83.8 \\
\hline $5^{\prime}$ & $6.97 \mathrm{~d}(8.4)$ & 116.3 & $6.94 \mathrm{~d}(8.5)$ & 116.0 & 5 & $3.45 \mathrm{~m}$ & 68.5 & $3.45 \mathrm{~m}$ & 68.4 \\
\hline $6^{\prime}$ & $7.65 \mathrm{dd}(8.4,1.9)$ & 124.1 & $7.64 \mathrm{dd}(8.5,2.1)$ & 123.9 & 6 & $1.15 \mathrm{~d}(5.7)$ & 18.1 & $1.22 \mathrm{~d}(6.2)$ & 18.2 \\
\hline \multirow[t]{14}{*}{$3^{\prime}-\mathrm{OCH}_{3}$} & $3.98 \mathrm{~s}$ & 56.8 & $3.99 \mathrm{n} \mathrm{s}$ & 57.0 & gal & & & & \\
\hline & & & & & 1 & $4.48 \mathrm{~d}(7.8)$ & 106.5 & $4.49 \mathrm{~d}(7.7)$ & 106.4 \\
\hline & & & & & 2 & $3.60 \mathrm{dd}(9.6,7.8)$ & 73.5 & 3.56 dd $(9.1,7.7)$ & 73.6 \\
\hline & & & & & 3 & $3.50 \mathrm{dd}(9.6,3.4)$ & 75.2 & 3.48 dd $(9.1,3.5)$ & 75.1 \\
\hline & & & & & 4 & $3.80 \mathrm{~d}(3.4)$ & 70.5 & $3.78 \mathrm{~d}(3.5)$ & 70.4 \\
\hline & & & & & 5 & $3.66 \mathrm{~m}$ & 75.3 & $3.66 \mathrm{~m}$ & 75.5 \\
\hline & & & & & 6 & $3.66 \mathrm{dd}(11.7,3.5)$ & 67.9 & $3.66 \mathrm{dd}(11.5,2.3)$ & 67.9 \\
\hline & & & & & $\begin{array}{l}6 \\
\text { rha-II }\end{array}$ & $3.84 \mathrm{dd}(11.7,5.5)$ & & $3.84 \mathrm{dd}(11.5,5.5)$ & \\
\hline & & & & & 1 & $4.75 \mathrm{~d}(1.6)$ & 102.2 & $4.75 \mathrm{brs}$ & 102.2 \\
\hline & & & & & 2 & 3.82 dd $(3.3,1.6)$ & 72.2 & $3.81 \mathrm{dd}(3.2,1.1)$ & 72.1 \\
\hline & & & & & 3 & 3.64 dd $(9.7,3.3)$ & 72.4 & 3.65 dd $(9.4,3.2)$ & 72.4 \\
\hline & & & & & 4 & $3.39 \mathrm{t}(9.7)$ & 74.0 & $3.39 \mathrm{t}(9.4)$ & 74.0 \\
\hline & & & & & 5 & $3.64 \mathrm{~m}$ & 69.8 & $3.64 \mathrm{~m}$ & 69.8 \\
\hline & & & & & 6 & $1.29 \mathrm{~d}(6.2)$ & 18.1 & $1.27 \mathrm{~d}(6.2)$ & 18.0 \\
\hline
\end{tabular}

Table 2

$\mathrm{IC}_{50}$ values of mushroom tyrosinase inhibition and antioxidant effects of $O$. amentacea leave extracts and compounds. Data were expressed as a mean value of three independent experiments.

\begin{tabular}{|c|c|c|}
\hline & DPPH radical scavenging activity & mushroom tyrosinase inhibition \\
\hline EtOH $70 \%$ extract and fractions & $\mathrm{IC}_{50}(\mu \mathrm{g} / \mathrm{mL})$ & $\mathrm{IC}_{50}(\mu \mathrm{g} / \mathrm{mL})$ \\
\hline EtOH $70 \%$ extract & $250 \pm 5.5$ & $509 \pm 15.2$ \\
\hline Fraction $\mathrm{A}_{1}$ & $>400$ & $>1300$ \\
\hline Fraction $\mathrm{A}_{2}$ & $300 \pm 5.2$ & $950 \pm 19.4$ \\
\hline Fraction $\mathbf{A}_{3}$ & $200 \pm 4.9$ & $326 \pm 5.1$ \\
\hline Fraction $\mathrm{A}_{4}$ & $380 \pm 7.2$ & $1200 \pm 20.2$ \\
\hline Fraction A5 & $>400$ & $>1300$ \\
\hline Fraction A6 & $>400$ & $>1300$ \\
\hline Isolated compounds & $\mathrm{IC}_{50}(\boldsymbol{\mu M})^{\mathrm{a}}$ & $\mathbf{I C}_{50}(\boldsymbol{\mu M})^{\mathrm{a}}$ \\
\hline 3 & $241.0 \pm 5.2$ & $>400$ \\
\hline 4 & $193.9 \pm 6.9$ & $>400$ \\
\hline 5 & $352.5 \pm 34.9$ & $>400$ \\
\hline 7 & $232.3 \pm 8.7$ & $>400$ \\
\hline 10 & $85.1 \pm 3.6$ & $42.1 \pm 0.2$ \\
\hline 11 & $42.1 \pm 3.2$ & $28 \pm 1.4$ \\
\hline Ascorbic acid ${ }^{b}$ & $56.8 \pm 0.08$ & - \\
\hline Kojic acid & - & $45.98 \pm 1.4 \mu \mathrm{M}$ \\
\hline
\end{tabular}

${ }^{\mathrm{a}} 50 \%$ inhibition not achieved at the concentration of $400 \mu \mathrm{M}$ for compounds $\mathbf{1 , 2 , 6 , 8}$, and $\mathbf{9}$.

${ }^{\mathrm{b}}$ Used as a positive control. 